\title{
Urbanization, gender and transport research issues and insights in Nigeria: Towards a sustainable gender sensitive transport development
}

\author{
R. A. Asiyanbola \\ Department of Geography and Regional Planning \\ Olabisi Onabanjo University \\ Ago-Iwoye, Ogun State, Nigeria
}

DOI: 10.36108/NJSA/0102/80(0120)

Vol. 8 Issue 1, 2010

\begin{abstract}
Urban transport, which serves as the sinew binding together various land-uses, has not only remained inefficient, but has grown over the years to be expensive and hazardous. Although, the situation of urban transport system in the Nigerian cities affects women and men, not until recently previous empirical and theoretical discussions most of the time assumed the universality of women's and men's experience. Every attempt at solving intra-urban mobility problems was made without gender considerations. The assumptions have always been such that the solutions are applicable equally to both men and women. In most cases, pure traditional economic variables which ignore crucial cultural roles and the salience of the life course are used to derive some of these solutions. Yet those missing variables are parts of our realities which of course need to be applied in formulating any transportation policy. The place of gender has been found to be very important in effective policy formulation because man and woman are not equal urban space users and actors. The paper provided an overview of gender and transport research and the policy implications towards a gender sensitive transport development in the Third World, particularly, Nigeria.
\end{abstract}

Keywords: urbanisation, transport research, transport development, gender, Nigeria

\section{Introduction: Urbanization and Urban Transport condition in Nigeria}

Trend in urbanization and city growth in developing countries are characterized by rapidity of urban increase, urbanization outpacing industrialization, and a high rate of urban population growth by natural increase and migration (Oyesiku, 2002a). In Nigeria, urbanization has a fairly long history in its growth and development. Historical account shows that extensive urban development in Nigeria predates the British colonial administration. Early explorers, missionaries and merchants estimates of population of towns show the existence of substantial human settlements in this part of the world in the 19th century (Mabogunje, 1968). During this period, the major factors crucial to the growth and development of cities were trading, marketing and administration. The second half of the 20th century witnessed rapid rate of urbanization and emergence of cities in various parts of Nigeria due to a number of factors among which are: introduction of wheeled transportation, particularly railway and road; categorization of settlement into hierarchical order of township; introduction of monetized economy and consequently production of cash crops and exploitation of mineral resources; continuous 

geopolitical restructuring, through creation of states and local governments in 1967, 1976, 1987, 1991 and 1996,; and the industrialization process between 1960 and 1975, which was based on import substitution strategies and consumer market for imported goods and services (Oyesiku, 2002a).

The pace of urbanization in Nigeria has been dramatic, showing extraordinarily high rates of 5-10 percent per annum (Egunjobi, 1999). As a result, there has been rapid expansion of Nigerian cities' area extent which is now sometimes ten fold their initial point of growth (Egunjobi, 1999; Ogunsanya, 2002; Oyesiku, 2002a). A crucial aspect of this is that city growth and expansion in Nigeria has been largely uncontrolled (Agbola, 1989; Agbola and Agbola, 1997; Egunjobi, 1999; 2002; Oyesiku, 2002a; Olanrewaju, 2004; etc). Consequently, the scaring and unsatisfactory situations in the cities have been increasing at an alarming rate. Egunjobi (1999:3) noted that our cities in Nigeria are not only ailing, quite a majority of them are on the verge of breathing the last breath. Several studies have shown that inadequate planning of urban land-uses in Nigeria and great intensity of use of land in the urban areas has exacerbated urban problems (Filani, 1994; Egunjobi, 1999; 2002; Oyesiku, 2002a; Foundation for Urban Development in Africa, 2006; etc). The current trend in the Nigerian cities is very frustrating. Mabogunje notes that whether we think of welfare services or employment opportunities, the urban system in Nigeria today is already proving inadequate as a means of achieving the type of social order that the country desires (Foundation for Urban Development in Africa, 2006:23).

In Nigeria, urban transport which serves as the sinew, binding together various land uses has not only remained inefficient, it has grown over the years to be expensive and dangerous (Egunjobi, 1999). In many Nigerian cities, urban transport exhibits remarkable features. Several studies have revealed these features of Nigerian urban transport (Adeniji, 1993; Adesanya, 1996; Adesanya and Adeniji, 1998; Torres, 2001; Oyesiku, 2002b, 2002b; Ogunsanya, 2002; Olukoju, 2003; Osita et al, 2003; Vandu-Chikolo, 2004, etc). Among these features as summarized by Oyesiku (2002b:257) is shown in Box 1.

\section{Box 1: Features of Urban Transport System in the Nigerian cities}

- $95 \%$ of urban trips are by road. Out of this, about $70 \%$ of the urban trips are made by public transport. Private operators dominate the public transport system and characterized by taxis, unregistered fare paying cars, para-transit, minibuses, two-wheeled motorcycle and three-wheeled motorcycle.

- Intermodality of trips is limited to public transport journey by road based public transport. The import of this is that most city travelers have no option of traveling by rail (light, metro, or tram) as well as by ferry.

- Ownership and organization of road public transport systems are characterized by haphazard and uncoordinated operators. 
- Complete absence of comprehensive and integrated of urban mass transit public transportation system. Proliferated and largely uncoordinated private operators of para-transit and motorcycles public transport services accompany this.

- Decrease in the supply of new vehicles of all types and depletion of existing fleet, since the middle of 1980s. For instance, there were 248 people to one vehicle in 1980, which declined to 600 people to one vehicle in 1998. The low level of motorization is partly connected with decline in the economic fortune of the country, high rate of inflation occasioned by continued pressure on the general domestic level has reflected in the double digits increase in the overall urban consumer prices for all items, and that for the transport in particular rising to the third digits.

- The rapid population growth and mismatched between urbanization and economic growth has led to inability of planners to adequately planned for existing cities and emerging settlements. The same gap between urbanization and economic growth has resulted in inadequate provisions for infrastructure and services, limp-frogging development in settlement that were never planned for and overall poor infrastructural base of the cities.

- Specifically poor condition of city roads which in turns shortens life span of motor vehicles and high cost of maintenance (Torres, 2001).

Source: Oyesiku (2002b:257)

Since Nigerian political independence in 1960, every successive government in the federation has shown appreciable concern for transport planning and development. This concern is reflected in the share of the transport sector out of the total planned public investment. As noted by Filani (2002), the transport sector has consumed on the average 20.3 percent of the total planned national resource outlay since the First National Development Plan Period (1962-1968). This according to him means that about 20 Kobo of every Naira in the planned expenditure in Nigeria's development efforts since 1962 had been allocated to the transport sector. Even though there had been significant achievement in this sector, it is still confronted with many problems which include among others, inadequate planning, lack of intermodal coordination, insufficient public transport to cope with rising demand, urban traffic congestion, etc. The enormous resources committed to the development of transport still remain inadequate. Hitherto, cities in Nigeria suffer from inadequate intra-connectivity (Filani, 2002; Oyesiku, 2002a; Ogunsanya, 2002; Egunjobi, 2002; Osita et al., 2003). There is lack of balance between urban structure and urban transportation system in Nigeria (Adeniji, 1993; Adesanya and Adeniji, 1998). Modal split is inappropriate due to the neglect of potentially viable modes of public transport, while the unbalanced capacity of networks create traffic congestion, excessive consumption of energy and environmental pollution (Adesanya and Adeniji, 1998). A significant proportion of roads in Nigerian have been crumbling due to overused and inadequate maintenance resulting in their deterioration. According to the World Bank Report, only 30 percent of all categories of road in Nigeria could 
be regarded as being in good condition; the remaining 70 percent is in different states of disrepair (Filani, 2002).

Filani (2002) notes that the country has the lowest level of motorization in West Africa with as low as 4 vehicles per 1000 inhabitants. To compound the problem further, the rate of vehicle growth is much lower than the population growth rate. Resulting from this mismatch is a general fall in the level of motorization in all parts of the country. Since 1982 and up till 1989/1990, there was a substantial reduction in new vehicle registration in all parts of the country (Fig. 2).

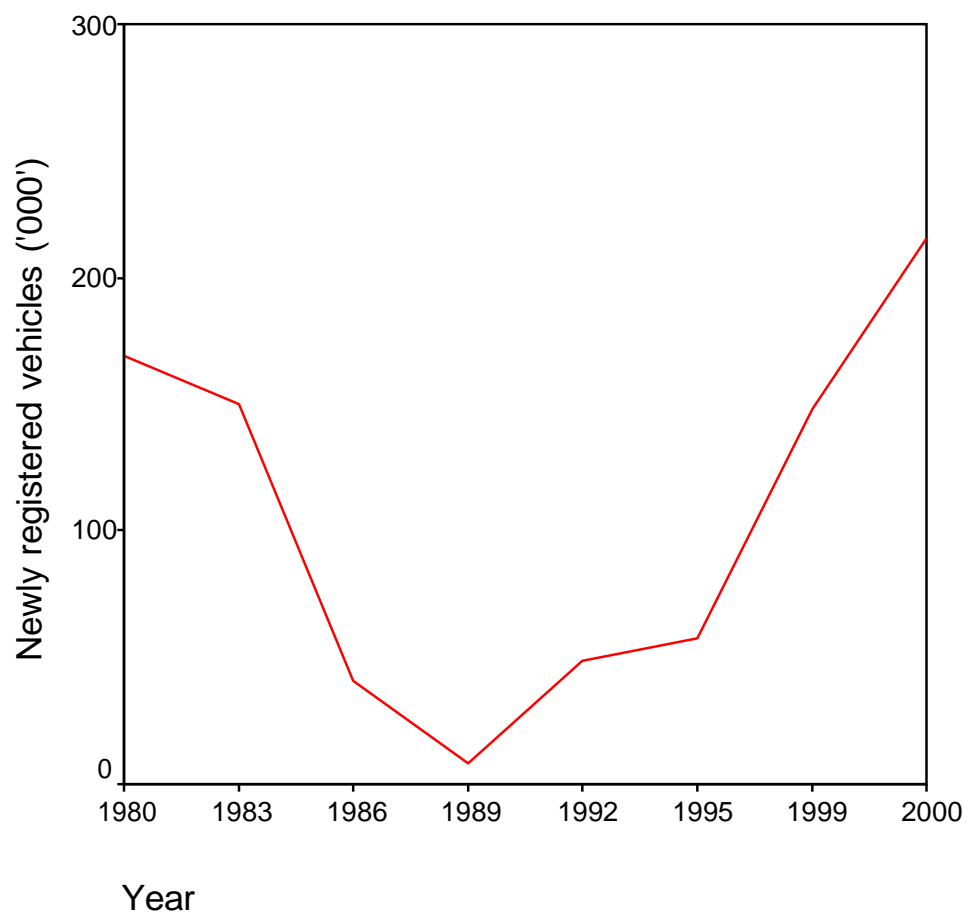

Fig. 2: Yearly trend of new vehicle registration in Nigeria (1980-2000)

Source: Federal Office of Statistics, Lagos

The reduction then is a reflection of the economic recession and the consequent stricter restriction on all categories of imports, which include private vehicles and spare parts. The slump in the oil revenue since 1983 resulted in the institution of Series of Economic Adjustment Program (SAP) in Nigeria. This involved the strict control of foreign exchange spending. Since SAP involved, among other things, adjustment of the local currency (Naira) to 
international convertible currencies as well as withdrawal of petroleum subsidy, vehicle prices and maintenance costs skyrocketed beyond the reach of most individuals in the country. The consequences are the following crises (Filani, 2002:40):

- high prices prevent the purchase of new vehicles; the astronomical prices of the available limited spare parts make vehicle maintenance almost impossible;

- public transport operators are saddled with rickety and ill-maintained vehicles due to exorbitant prices of spare parts and their inability to purchase new ones to expand their fleet of vehicles; and

- queues of passengers at major urban terminals and along routes get longer and longer everyday.

Mabogunje notes that most of the problems faced by African cities stem from the fact that urban population are growing faster than urban economies (Foundation for Urban Development in Africa, 2006:25). All the crises highlighted above have resulted from serious distortion and gap which have been created between demand and supply of means of mobility among the populace (Filani, 2002). The demand for public transport among Nigerians, especially those living in the urban centres has increased to a scale hitherto unprecedented.

Thus, even though, the role of urban transportation is to facilitate the movement of people and goods comfortably and safely, when they are required and recognizing that there is no alternative to mobility, what exists in the Nigerian cities are a litany of inconvenience, and frustration (Egunjobi, 1999, 2002; Osita et al., 2003; Olukoju, 2003; Asiyanbola, 2004). Transport infrastructure is inadequate and the available public transport facilities are not adequately maintained.

\section{Gender and Transport}

Although the situation of urban transport system in the Nigerian cities affects women and men, previous empirical and theoretical discussions most of the time assumed the universality of women and men's experience (Seager, 1992; Moser, 1992, 1993; McDowell, 1983; Weisman, 1992; Robinson, 1998, etc.). Hitherto, every attempt at solving intra-urban mobility problems was made without gender considerations. The assumptions have always been such that the solutions are applicable equally to both men and women. In most cases, pure traditional economic variables which ignore crucial cultural roles and the salience of the life course are used to derive some of these solutions (Rosenbloom, 1993). Yet those missing variables are parts of our realities which of course need to be applied in formulating any transportation policy. The place of gender has been found to be very important in effective policy formulation because man and woman are not equal urban space users and actors (Townsend, 1991; Seager, 1992; Moser, 1993; Bowlby et al, 1989; Short, 1996; etc). 
Up till the 1970s, women generally, are noticeably absent from the discussion of development theory and practice. They have remained invisible in many analyses of social space. In fact, Robinson (1998) notes that with respect to the human geography techniques and models many of which originated within geography from the pioneering studies in the 1960s, they were applied in research and completely ignored gender. According to him, although there were references to consumers, decision makers and heads of household, there was no attempt to distinguish between the different realities confronting men and women, and the differential power relations associated with gender (Jackson, 1990). Gender was largely a taken-for-granted variable and the different nature of women's lives was simply ignored.

Not until recently, studies, mostly in the advanced countries, have sought to uncover women's experience of different places. Such studies according to Robinson (1998: 456) have often thrown into sharp focus the different types of experience of place had by men and women. Some of such recent researches based on sex differentiated data have shown clearly that there is gender differences in spatial experiences and that differences between women and men run through all aspects of urban life: in commuting patterns and transportation use; in patterns of housing and homelessness; in labour force participation and work opportunities and in the use of urban social space (Seager, 1992; Weisman, 1992; etc).

In the developed countries since the 1970s, there has been growing awareness of wide differences in the ways in which men and women travel (Beuret, 1991).This increasing awareness is from studies carried out on women and transportation. Box 2 shows highlight of some of these research findings in the developed countries.

\section{Box 2: Highlight of research findings on gender and travel in the developed countries}

- Women's transportation patterns differ from men's on several dimensions: the journey-to-work trip; the kind of trips made, complexity of trip-making, and the use of public transit (Wekerle, 1980; Gordon et al, 1989; Hanson and Johnson, 1985; Schintler, 2001; etc).

- Work trip is shorter for women than for men (Rutherford and Wekerle, 1989; Pisarski, 1987; Nelson, 1986; Singell and Lillydahl, 1986; Hanson and Johnson, 1985; Pickup, 1985; Dasgupta, Frost and Spence, 1985; Michelson, 1983. Howe and O'Connor, 1982; Madden, 1981; Ericksen, 1977; Gordon, Kumar and Richardson, 1989 etc.). This result holds in spite of differences in public transit versus automobile use and in female labor force participation rates. Women try to reduce the distance between home and work and the time spent in commuting; the shortest journey to work is found among married women.

- Working women made more domestic related trips and chauffeuring children than their spouses (Hanson and Hanson, 1980; Prevedourous and Schofer, 1991).

- Single parents made more trips and traveled further for all purposes than 
comparable married workers (Kostyniuk et al, 1989; Johnson-Anumonwo, 1989; Rutherford and Wekerle, 1989).

- Age and presence of children influenced travel patterns in all types of household. Women's travel patterns varied significantly with the age of their youngest child (Rosenbloom and Raux, 1985; Perez-Cerezo, 1986).

- Women's entry into the workforce, along with their continued role as primary caretakers of domestic responsibilities, has led to the emergence of "knock-on" trips, or trips generated by the substitution of home production for market production. Women are more likely than men to make these types of trips. (Rosenbloom, 1993; Schintler, 2001).

- Complex travel behavior such as trip chaining is more common for women than men even when both males and females are in employment. Women stop more for running household errands than do men, on both inward and outward commutes and irrespective of the number of persons in a household or its structure (Root et al, 2000; Schintler, 2001).

- Married women are more likely to make a greater variety of trips for young children, and more of those trips are directly related to household responsibilities (Rosenbloom, 1989).

- Women frequently use public transportation for shopping and household errands and women workers combine these trips with the journey to work to save precious time (Skinner and Borlaug, 1978; Hanson and Hanson, 1978; Beuret, 1991).

- Within the same households, men and women often have differential access to family car, where there is only one automobile, it is frequently the husband who uses it on a regular bases (Wekerle, 1980; Hanson and Hanson, 1980; Beuret, 1991; Rosenbloom, 1993).

- In studies of traveller information services, women are often less prone to switch routes after receiving traveller information on alternative routes. Women tended to be more conservative in their selection of travel alternatives (Abdel-Aty et al., 1996; Schintler, 2001).

- Motor vehicles crashes by gender study show that males had more severe crashes than females and shows riskier behaviour for every crash type. Ned (2011). Compared with older male drivers, older female drivers are at a greater risk for injuries from crash-related violations and driving error (Sherrileine et al., 2011).

Historically, transportation planning and engineering have been gender neutral. The needs and responsibilities of women which now extend beyond the domestic sphere, due largely to the increase in female labour force participation play an important role in shaping their travel activity patterns, specifically, in their impact on trip purpose, frequency and distance travel, mode of transportation used, and complexity of trip making. However, as observed in the literature, transportation planning models are not designed to capture these differences (Wekerle, 1980; Schintler, 2001). The design of the transportation systems is such that it is primarily to carry workers to and from their jobs. Planning does not take into account the fact that the journey to work for women workers is often more time consuming, more costly, and more complicated than men's. Women frequently use public transportation for shopping and household errands and women workers combine these trips with 
the journey to work to save precious time (Skinner and Borlaug, 1978; Hanson and Hanson, 1978). Yet fare structures and the location of transit lines do not accommodate these trips pattern.

In addition, mothers are generally responsible for taking children to childcare facilities and picking them-up. These trips are not reflected in transportation models even though they require an extra trip twice a day; sometimes in a direction away from work, and involve additional time and money (Wekerle, 1980). These models according to Schintler (2001:356-357), assumed that each traveller's primary concern is to minimize travel time and cost, whereas other factors such as safety, comfort, and accessibility to opportunities may be more important than travel time to many women, and that the unique circumstances and psychology of women may lead them to very different rules of travel related decision-making than men, and this behaviour cannot be accurately reflected in travel demand models based on rational behaviour and utility maximization.

In the developing countries and in Nigeria in particular, studies have shown that there are significant differences between women and men intraurban travel behaviour (Asiyanbola, 1999, 2002; Fadare and Morenikeji, 2001; Oyesiku and Odufuwa, 2002). A study carried out in Abeokuta, Ogun State revealed that women linked-trips to and from work; women make more activity trips weekly than men and women and children depend heavily on public transport for their intra-urban travel (Asiyanbola, 1999). Observation in Ibadan city revealed that work trip distance is shorter for women than for men. Women make domestic related non-work trips more than men and walking as well as public transport are crucial in enabling access to various activities centers; and in a household where there is one car, men use the car most (Asiyanbola, 2002). In Niger State, Fadare and Morenikeji (2001) found that among people without means of transport, women make more trips than men, but among the group with means of transport, men have a higher mean trip rate than women. Also, study by Oyesiku and Odufuwa (2002) on gender perspectives in travel behaviour of motorcycle passengers in Nigerian intermediate cities, shows that females frequently use motorcycle mode for short and long distance trips more than males. The use of motorcycle has significant effects on the pattern of dressing of women and that two of every three passengers that have motorcycle accidents are women. An empirical study from three countries in sub-Saharan Africa (Ghana, Malawi and South Africa) explored the gendered nature of children journey to school found that journey to school represents a particularly hazardous enterprise for girls because they face a very serious threat of rape. Also that girls' journey to school and school attendance are hampered by Africa's transport gap and cultural conventions that require females to be responsible for pedestrian head loading (transporting loads such as food crops and fuel on the head) and other work before leaving for, or instead of attending, school (Gina et al, 2011). 
World Health Organization (2000) recently articulated that health concerns related to traffic and transportation have become a worldwide phenomenon and will likely become more of an issue in the future. Recent studies suggest that stress from transportation may represent an important factor that influences the well-being of urban population (Asiyanbola, 2004; Gee and Takeuchi, 2004). In Nigeria, recent study by Asiyanbola (2007) shows that urban transport infrastructure condition and intra-urban travel constitute a major threat to psychological well-being of women and men and the effect is more on the psychological well-being of women than of men due to gender differences in the socially prescribed roles. In Nigeria, patriarchy structure has been a major feature of the traditional society (Aina, 1998). It is a system of social stratification and differentiation on the basis of sex, with clearly defined sex roles (Aina, 1998:6). Traditionally, men do not participate in domestic work including child rearing - such tasks are considered to be the exclusive domain of women. The traditional stereotype in the division of labour within the domestic units is still rampant and women even if employed and regardless of social class still do the greatest share of household and childcare activities (Asiyanbola, 2006a). Grieco and Turner (1997) notes that women's greater domestic responsibilities, coupled with their weaker access to household resources have significant consequences on their transport and travel status. According to them, the lower the income of a household, the more probable it is that women experience greater transport deprivation than men, which may take the form of women's journey having multiple purposes and thus generating greater anxiety in the travel context (Grieco and Turner, 1997:4647). In most communities and neighborhoods, where basic amenities and infrastructures are in a very deplorable situation, women are forced to make several daily trips e.g. to the water source.

\section{Policy Implications and Conclusion}

The issue of concern, therefore, is to make transport services not only affordable, accessible, safe and appropriate, but also gender sensitive. This will facilitates the achievement of the Millennium Development Goal, Number 3, which is to promote gender equality and empowerment. This is because, services which are gender-sensitive would improve the potential of women to enjoy and exercise their full human rights - political, economic, social, civil and cultural; would facilitate greater equality between women and men; and would contribute to greater equity (O'Connell, 2000:9). To achieve this, there is need for the involvement of women in discussions and decision-making that shapes service delivery. Of course, policies to improving the socio-economic status of women should be pursued, as this will increase the number of women that could be involved in policy making process. This is because studies have shown that women and men do not have equal access to, or influence on, decision-making and that socio-economic status of women is an important factor that make women participate more or less in decision-making (Olatubara, 2003; Asiyanbola, 2006b). This will also reduce the frequency of 
trips made by women as the result of the correlation analysis between intraurban travel and socio-economic characteristics of working women suggested, thereby reducing the psychological distress due to intra-urban transportation. Among local decision makers - elected representatives, officials, service planners, and deliverers - and civil society organizations including NGOs and community-based organizations, there is the need to build greater awareness and sensitivity to gender differences, as these are fundamental to developing gender sensitive services (O'Connell, 2000). In addition, and more importantly, there is the need to invest in reducing and redistributing women's workload as this will enhance women empowerment and facilitates the achievement of the Millennium Development Goal, Number 3.

There is need to develop transportation planning models that capture gender differences in trip purpose, frequency and distance travel, mode of transportation used and complexity of trip making. There is need to improve public transport. This could be achieved through increasing subsidies in order to reduce fares or increase services, providing more buses, staff, stations and bus stops. Improving safety on the street is very crucial. Routes should connect homes with other activity centers. There is an urgent need for planning, that is, urban development and transport have to be pursued together at the same time. Provision of efficient public transport should precede any major housing development. Measures should be taken to avoiding alienation of any existing right-of-way, especially in the dense areas. A design of integrated metropolitan transport master plans with a clear vision of train, bus and taxis as well as urban motorcycle and non-motorized transport roles is needed. Urban transportation policies, which emphasize accessibility, that is, reducing the need to travel, should be pursued. Such policies relate to land use planning, decentralization of activity areas and the prioritization of walking and cycling over motorized transport.

\section{References}

Abdel-Aty, M.; R. Kitamura \& P. Jovanis. 1996. Investigating effects of travel time variability on route choice using repeated-measurement stated preference data, Transportation Research Record, 1493:39-45.

Adesanya, S. 1996. Public transport operation in Nigeria, In Bolade, T. \& Adeyemi E. O. Enhancing the efficiency of Mass Transit operation in Nigeria, Rex Charles \& Connel, Ibadan.

Adesanya, A.O. \& Adeniji, S.A. 1998. Sustaining urban public transport in Nigeria: critical issues and remedies, in Freeman \& Jamet (eds.) Urban Transport Policy. Balkema, Rotterdam, pp. 775-781.

Adeniji, K. 1993. Transport subsidies in Nigeria: A Synopsis of Workshop Proceedings, NISER, Ibadan \& Friedrich Ebert Foundation, Germany. 
Agbola. T. \& Agbola. E.O. 1997. The Development of Urban and Regional Planning Legislations and their impact on the Morphology of Nigerian Cities. The Nigerian Journal of Economic and Social Studies, Vol. 39(1): 123-144.

Agbola, T. 1989. Perspective planning: the urban and regional planning dimensions. The Nigerian Journal of Economic and Social Studies, 31 (1, 2 \& 3).

Aina, I. Olabisi. 1998. Women, culture and Society, in Amadu Sesay and Adetanwa Odebiyi (eds). Nigerian Women in Society and Development. Dokun Publishing House, Ibadan.

Asiyanbola, R.A. 1999. Women Intra-Urban Travel Pattern: A case study of Abeokuta, Ogun State Nigeria. Ife Social Science Review. 17(2): 62 -72.

Asiyanbola, R.A. 2002. Gender differences in intra-urban travel behaviour: A preliminary survey in Ibadan, Nigeria, in Xavier Godard and Innocent Fatonzoun (eds.) Urban Mobility for All, Lisse: A.A. Balkema, The Netherlands pp. 29-35.

Asiyanbola, R.A. 2004. Les contraintes du voyage intra-urbain dans un pays en cours de development - Nigerie (Intra-urban travel stress in a developing country - Nigeria), in the CODATU XI International Conference Proceedings on 'Towards More Attractive Urban Transportation' held at Bucharest, Romania.

Asiyanbola, R.A. 2006a. Gender, Household Sex Roles, Work, and Contemporary Yoruba Family, in Toyin Falola \& Ann Genova (eds.) The Yoruba in Transition: history, Values and Modernity. Carolina Academic Press, North Carolina, USA, pp. 445 - 462.

Asiyanbola, R.A. 2006b. Residential Location decision making and gender in Nigeria. Geoforum 37 pp. 1059-1065.

Asiyanbola, R.A. 2007. Intra-urban transportation, gender and psychological distress in developing countries: Nigeria. A paper presented at the Workshop on: Urban Population, Development and Environment dynamics in developing countries, organized by the Committee for International Cooperation in National Research in Demography (CICRED), in collaboration with the Population-Environment Research Network (PERN) and the Center for International Earth Science Information Network (CIESIN) of Columbia University; $11^{\text {th }}-13^{\text {th }}$ June 2007 - Nairobi, Kenya.

Beuret, Kristine. 1991. Women and Transport, in Mavis Maclean and Dulcie Groves (eds.) Women's Issues in Social Policy. London: Routledge, pp. 6175.

Bowlby, S.; Lenis, J.; McDowell, L. \& Foord, J. 1989. The Geography of Gender. In Peet, R. and Thrift, N. J. (eds.) New Models in Geography, Vol. 2 London: Unwin Hyman, 157-175.

Dasgupta, M.; Frost, M. \& Spence, N. 1985. Interaction between urban form and mode choice for the work journey: Manchester Sheffield 1971-1981. Regional Studies 19: 315-28. 
Egunjobi, L. 2002. Planning the Nigerian Cities for Better Quality of Life, in Onakomaiya S.O. \& Oyesiku O.O. (eds). Environment, Physical Planning and Development in Nigeria, Department of Geography and Regional Planning, Olabisi Onabanjo University, Ago-Iwoye, Nigeria, pp. 89-107.

Egunjobi, L. 1999. Our Gasping Cities An Inaugural Lecture delivered at the University of Ibadan on Thursday, 21st October.

Ericksen, A.J. 1977. An analysis of the Journey to Work for Women. Social Problems 24, pp. 428-35.

Fadare, S.O. \& Morenikeji, W. 2001. Gender-bias in intra-urban trip patterns in Niger State, Nigeria, International Journal of Transportation Studies, 1(1): 73-85.

Filani, M.O. 2002. Mobility Crisis and the Federal Government's Mass Transit Programme, in Onakomaiya S.O. \& Oyesiku O.O. (eds.). Environment, Physical Planning and Development in Nigeria, Department of Geography and Regional Planning, Olabisi Onabanjo University, Ago-Iwoye, Nigeria, pp. 37-51.

Foundation for Urban Development in Africa. 2006. The Legacy of Akin Mabogunje, The Cities Alliance, Washington DC, USA.

Gee, Gilbert C. and David, T. Takeuchi. 2004. Traffic stress, vehicular burden and well-being: A multilevel analysis, Social Science and Medicine Vol. 59, pp. 405-414.

Gina, Porter; Kate, Hampshire; Albert, Abane; Alister, Munthali; Elsbet, Robson; Mac, Mashiri \& Augustine, Tanle. 2011. Youth transport, mobility and security in Sub-Saharan Africa: The gendered journey to school. Conference Proceedings 46 on Women's Issues in Transportation, Transportation Research Board of the National Academies Washington D.C. Pp. 105-116.

Gordon, P.; Kumar, A. \& Richardson, H.W. 1989. Gender Differences in Metropolitan Travel Behavior. Regional Studies, Vol. 23(6): 499-510.

Grieco, Margaret \& Turner, Jeff. 1997. Gender Issues in Transport, International Forum on Urban Poverty Proceedings of the International Conference on Urban Poverty, 9-13 Nov., Florence, Italy, HABITAT, pp. 46-47.

Hanson, S. \& Johnson, I. 1985. Gender differences in work trip length: explanations and implications. Urban Geography, 3: 193-219.

Hanson, S. \& Hanson, P. 1978. Impact of women employment on Household Travel Patterns. Papers presented at the conference on women's transportation, Washington D.C Sept. 1978.

Handson, S. \& P. Handson. 1980. Gender and urban activity patterns in Uppsala, Sweden, Geographical Review, 70:291-299.

Hanson, S. \& Hanson, P. 1980. The impact of women's employment on Household travel patterns: A Swedish example, in S. Resenbloom (ed.) 
Women's Travel Issues. Washington D.C, U.S Government Printing Office.

Howe, A. \& O'Vonnor, K. 1982. Travel to work and labour force participation of men and women in an Australian metropolitan area. Prof. Geogr. 34/50-64.

IFRA. 2002. Choes, Cities and Artists in Nigeria. Ibadan: French Institute for Research in Africa (IFRA), pp. 2-3.

Ikporukpo, C.O. 1994. The Urban Transport Crisis and Urban Violence: Reflections on the Nigerian Situation. In Albert I.O., Adisa J., Agbola T. \& Herault G. (eds.) 1994. Urban Management and Urban Violence in Africa. Proceedings of the International Symposium held at Ibadan, Nigeria, 7-11 November 1994. Ibadan: IFRA, pp. 21-28.

Jackson, P. 1990. The Cultural Politics of Masculinity: Towards a Social Geography. Transactions of the Institute of British Geographers, 16: 199213.

Johnson-Anumonwo, I. 1989. Journey to Work: A Comparison of characteristics of Single and Married Parents. Journal of Specialized Transportation Planning Practice, 3(3):219-246.

Kostyniuk, L.P. et al. 1989. Mobility of single parents: What do the records show? Journal of Specialized Transportation Planning and Practice 3: 307.

Mabogunje, A. L. 1968. Urbanization in Nigeria; London: University of London Press Ltd.

Madden, J.F. 1981. Why women work closer home. Urban Studies, 18, 181-94.

Mackenzie, Susanne. 1989. Women in the City, in Peet Richard and Thrift Nigel (eds.) New Models in Geography, vol. II. Unwin Nyman London. P. 109-126.

McDowell, L. 1983. Towards an Understanding of the Gender Division of Urban Space. Environment and Planning the Society and Space. 1: 59-72.

Michelson, W. 1983. The impact of changing women's roles on transportation needs and usage. US Department of Transportation, Washington DC.

Moser, C.O.N. 1992. Housing, in Ostragaard Lise (ed.) (1992) Gender and Development: A Practical Guide, London: Routledge, pp. 76-93.

Moser, C.O.N. 1993. Gender, Planning and Development: Theory, Practice and Training, London: Routledge.

Ned Levine. 2011. Spatial variation in motor vehicle crashes by gender in the Houston, Texas, Metropolitan area. Conference Proceedings 46 on Women's Issues in Transportation, Transportation Research Board of the National Academies Washington D.C. Pp. 12-25

Nelson K. 1986. Labour demand, Labour supply and the suburbanization of low-wage office work, in Scott A. J. \& Storper M. (eds.) Production, Work, Territory. Allen and Unwin, Boston.

O'Connell, Helen. 2000. Introduction, Report: One World Action Seminar Developing Gender-sensitive Local Services. London: The British Council, 28-29 June, pp. 9-14. 
Ogunsanya, A.A. 2002. Makers and Breaker of Cities. The Fifty-ninth Inaugural Lecture delivered at the University of Ilorin on Thursday, June 27.

Olanrewaju, D.O. 2004. Town planning: A veritable means for poverty reduction, Inugural Lecture Seris 38, delivered at The Federal University of Technology, Akure on 26th October, 2004.

Olatubara, C.O. 2003. The participation of women in residential location decision-making in Ibadan, Nigeria, Journal of the NITP, XVI(1):19-33.

Oyesiku, O.O. 2002a. From Womb to Tomb. 24th Inaugural Lecture, Olabisi Onabanjo University, Ago-Iwoye, 27th August.

Oyesiku, O.K. 2002b. Policy framework for urban motorcycle public transport system in Nigerian cities, in Xavier Godard and Innocent Fatonzoun (eds.) Urban Mobility for All, Lisse: A. A. Balkema, pp.255-261.

Oyesiku, O.O. \& Odufuwa, B.O. 2002. Gender perspectives in travel behaviour of motorcycle passengers in Nigerian intermediate cities, in Xavier Godard and Innocent Fatonzoun (eds.) Urban Mobility for All, Lisse: A. A. Balkema, The Netherlands pp. 13-19.

Olukoju, Ayodeji. 2003. Infrastructure Development and Urban Facilities in Lagos, 1861-2000. Occasional Publication No. 15, Ibadan: IFRA.

Osita, Nwajah; Ibim, Semenitari; Anene, Ugoani; Stephen, Ubanna; Dele, Oyewale \& Ann, Ariole. 2003. Infrastructure: A Rotten Foundation. TELL Nigeria's Independent Weekly No. 23 June 9, pp. 47-50.

Perez-Corezo, J. 1986. Women commuting to suburban employment sites: An activity based approach to the implications of ISM plans. Report, Institute of Transportation Studies, University of California, Berkeley, CA.

Pickup, I. 1985. Women's Travel Needs in a period of Rising Female employment, in G. Jansen et al (ed.) Transportation and Mobility in an era of Transition, Amsterdam: Elservier, North Holland.

Pisarski, A.E. 1987. Commuting in America. Eno Foundation for Transportation, Westport, Connecticut.

Prevedouros, P. \& Schofer, J.L. 1991. Trip characteristics and travel pattern of suburban residents. Paper presented at the 70th Annual meeting of the Transportation Research Council, Washington, D.C.

Robinson, M. Guy. 1998. Method and Techniques in Human Geography, New York: Wiley.

Rosenbloom, S. \& Raux C. 1985. Employment, child care and travel behaviour: France, The Netherlands and the United States, in Behavioural Research for Transport Policy, Utrecht, The Netherlands: VNU Science Press.

Rosenbloom, S. 1989. The impact of growing children on their parents' travel behaviour: a comparative analysis, Transportation Research Record, 1135. 
Rosenbloom, S. 1993. Women's Travel Patterns at Various Stages of their lives, in Cindi Katz and Jainice Monk (eds.) Full Circles: Geography of Women Over the Life Course, London: Routledge, pp. 208-242.

Root, A.; Schintler \& K.J. Button. 2000. Women, travel and the idea of 'sustainable transport, Transport Reviews, 20: 369-383.

Rutherford, B.M. \& Wekerle, G.R. 1989. Single parents in the suburbs: Journey to work and access to transportation. Journal of Specialized Transportation Planning and Practice 3(4):277-94.

Seager, Joni. 1992. Women Deserve Spatial Consideration or Geography like no one ever learned in School, in Chens K. \& Dale S. (eds.) The Knowledge Explosion: Generations of Feminist Scholarship, London: Athene Series, Teachers College, pp.212-224.

Schintler, Laurie A. 2001. Women and Travel, in Button, K.J. \& Hensher, D.A. (eds.) Handbook of Transport system and Traffic Control. New York: Pergamon-Elsevier Science Ltd., pp. 351-358.

Sherrilene, Classen; Orit, Shechtman; Youngsung, Joo; Kezia, D.; Awadzi \& Desiree, Lanford. 2011. Traffic violations versus driving errors: Implications for older female drivers. Conference Proceedings 46 on Women's Issues in Transportation, Transportation Research Board of the National Academies Washington D.C. Pp. 55-63.

Short, J.R. 1996. The Urban Order: An Introduction to Cities, Culture and Power. USA: Blackwell.

Singell, L.D. \& Lillydahl, J.H. 1986. An empirical analysis of the commuter to work patterns of males and females in two-earner households, Urban Studies 2, 119-29.

Skinner, Louise \& Borlaug, Karen. 1978. Shopping Trips: Who makes them and when? Papers presented at the conference on women's travel issues. U.S Department of Transportation, Washington D.C.

Torres Martinez, A.J. 2001. Road maintenance policies in Sub-Saharan Africa: unsolved problems and acting strategies, Transport Policy, 8 (4): 257-266.

Townsend, J.G. 1991. Towards a Regional Geography of Gender. The Geographical Journal, 157(1): 25-35.

Vandu-Chikolo, I. 2004. Urban Transport Infrastructure, in Vandu-Chikolo I, Ogunsanya Ade A. \& Sumaila A. G. (eds.) Perspectives on Urban Transportation in Nigeria. A publication of the Nigerian Institute of Transport Technology (NITT), Zaria, pp. 70-86.

Weisman, L. Kanes. 1992. Designing Differences: Women and Architecture, in Kramarae Chens \& Spender Dale (eds.). The Knowledge Explosion: Generations of Feminist Scholarship, London: Athene Series, Teachers College Press, pp. 310-320.

Wekerle, G.R. 1981. Women in the Urban Environment. Signs: Journal of Women in Culture and Society, 5:3, pp. 188-214.

World Health Organization. 2000. Transport environment and health. Copenhagen: WHO Regional Publication, European Series. 